\title{
Research on the Development and Current Situation of Teaching Mode Under the Background of Information- ization at Home and Abroad
}

\author{
Zhibin Zhang ${ }^{1}$, Xianzhen Ren ${ }^{2}$, Xiuhua Geng ${ }^{3}$ and Wei Liu ${ }^{4}$ \\ ${ }^{1,2,3,4}$ Software and Information Department Beijing Information Technology College Beijing China \\ *Corresponding author.Email:zhangzb@bitc.edu.cn
}

\begin{abstract}
accelerate the education informatization construction is not only the important content of deepening the reform of vocational education teaching, and teaching mode, changing to adapt to a new generation of the inevitable trend of the informationization process of education informatization which includes the construction of the digital teaching resources and teaching mode innovation and reform, based on the information environment based on the field of vocational education as the object, the teaching mode under the background of informatization development and present situation at home and abroad research.
\end{abstract}

Keywords: informationization, Teaching mode, home and abroad, Current situation.

\section{INTRODUCTION}

Since the eighteenth congress, informatization has become an important strategy, the national development "Internet +", big data, cloud computing, a new generation of artificial intelligence and other major strategic policies introduced frequently, become the education informatization rapid evolution driven by the engine, "everyone, everywhere to learn, to learn all the time" the personalized learning scenario has been build to shape. In April 2018, the Ministry of Education issued the "Education Informatization 2.0 Action Plan", which became the key content and important symbol of "Education Modernization 2035". The action plan points out that after years of exploration and practice, the revolutionary impact of information technology on education has initially appeared, but it still falls far short of the requirements of the new era. The development and service ability of digital education resources is not strong, the construction and application level of information-based learning environment is not high, the application ability of teachers' information technology is basically good, but the innovation ability of information-based teaching is still insufficient [1].

Since 2003, the state has launched the national highquality curriculum construction project, the construction project of professional teaching resource database and the Construction project of Open Courses in Chinese universities, which, to a certain extent, has driven colleges and universities to build a certain amount of digital teaching resources based on their own actual conditions. In recent years, with the presentation, the teaching video, micro lesson, lesson plans, base, putted forward the quality of the digital resources present a number of redundancy, far-fetched, revolves around the digital resources of online teaching, remote education, hybrid teaching mode to carry out the crossover, but meet the characteristics of poor students individualized learning effect, in this paper, the teaching mode under the background of informatization related research at home and abroad for carding and analysis, aims to clarify the problems and provide reference to improve teaching effect.

\section{THE DEVELOPMENT OF TEACHING MODE UNDER THE BACKGROUND OF DOMESTIC INFORMATIZATION}

Throughout the domestic teaching mode reform under the background of informatization development course, dates back to the late $1990 \mathrm{~s}$, with the development of multimedia technology in the domestic, presentations, documents, animation and other digital resources gradually into teaching assisted by multimedia, formed in the students as the center of teaching mode, gradually replaced with teachers as the main body of 
one-way knowledge infusion of traditional teaching mode; Since 2007, China has entered the exploratory research stage that focuses on students' high-level ability. Concepts such as autonomous learning, constructivism, task-based teaching and computer network teaching have been repeatedly practiced, but there is no breakthrough. In 2013, with the rapid development of Internet technology and mobile technology, represented by "flip" classroom education based on Internet platform, highlighting "guides the student to explore independently, stimulate interest in learning" for the characteristics of heuristic teaching mode arises at the historic moment, turning the classroom will learn the decision from teachers to students, by students to plan their own learning, learning rhythm, and presents the way of knowledge, to assist in guiding role for teachers to help students complete the personalized learning. Since then, the number of digital resources such as presentations, teaching videos and micro-classes has grown rapidly. The emergence of the "flip" classroom teaching mode for our country enters the education information on a new step, the heuristic teaching mode of improving the students' learning experience and teaching effect, the teachers and students to a certain extent recognition, at this stage, there have been longed for class/MOOC, SPOC, PBL, hybrid, and many other teaching mode, teaching by using Internet technology to carry out the heuristic, exploratory, participatory teaching activities and encourage the developmental evaluation, change "to the classroom as the center" to "classroom and extracurricular", exploring with learners as the center, establish collaborative teaching and learning the new teaching mode gradually been staged teaching process; In 2018 the ministry of education issued the action plan for education informationization 2.0, point out the positive role of education informatization and the development tendency, at the same time as the Internet, data, information resources, such as mobile communication technology and network learning environment, the explosive development of the Internet "connected, open, sharing", the characteristics of the school teaching from closed to open, 2019 year end of the tail and head of the outbreak, will be fully launched online teaching, online education in the outbreak time also will inevitably in the course of all or part of a vision into the school curriculum reform, As a result, online teaching modes such as "blended teaching", "flipped classroom", MOOC, SPOC, etc. are widely promoted and applied.

\section{THE DEVELOPMENT OF TEACHING MODE UNDER THE BACKGROUND OF FOREIGN INFORMATIONIZATION}

Under the background of information technology, the development of classroom teaching mode in foreign countries started earlier than that in China. In the early 1980s, multimedia and computer-aided teaching with emphasis on professional development appeared. The use of computers and the research on students' independent learning motivation have quietly begun, but still remain in the stage of traditional teaching mode. In 1996, multimedia computer technology and auxiliary resources were used to strengthen the teaching design, thus encouraging students to explore independently and reflect on the learning content and process of problemoriented teaching mode was promoted. Multimedia technology, computer - aided, problem - oriented, assessment and so on pay attention to student learning guidance discussion frequently appear; From 2006 to 2011, also put forward to cultivate students' ability of higher order as the core of the heuristic teaching mode, pay attention to training students' critical thinking and decision-making ability, information literacy, problem solving skills, team work and self management ability, based on computer network appeared during the period of the E - Learning (electronic Learning) concept, strengthen the curriculum setting, evaluation assessment, autonomous Learning, Learning motivation and other factors that affect the teaching effect; In 2012, due to the rapid development of network and information technology, in order to improve the students learning motivation and participation as the core, based on the Internet platform of network teaching model plays a different role in succession, hybrid, flip the classroom, digital learning, case teaching has been applied different scenarios, puts forward higher requirements to the interesting of digital resources. At present, "Mo-tivation" and "engagement" are listed as two important indicators to evaluate the teaching effect in foreign countries. At the same time, with the further development of electronic learning, Internet and artificial intelligence, personalized learning and mixed teaching based on Internet platform have gradually become the mainstream of the current teaching mode [2].

\section{CONCLUSION}

Through the above analysis, since the 80 s modern, global education teaching mode of exploration followed by information technology and digital resources development as the guide conditions mature, the domestic study of the teaching patterns started later than abroad, due to foreign early into the multimedia auxiliary teaching stage, Internet, software in domestic, in addition, domestic, this paper probes into the application problem of focuses on teaching abroad pay more attention to the study of the education teaching theory, The design of teaching process is emphasized in China, while the evaluation of teaching effect is emphasized in foreign countries. In China, we pay more attention to the design of teaching resources and the exploration of teaching mode, while in foreign countries, we pay more attention to the study of students' participation and learning motivation. 
Through a large number of social experiments, foreign scholars have shown that the low participation of students is the main reason for the low learning productivity of students, especially in Internet teaching. Under the background of the rapid development of MOOC and other online teaching platforms, the teaching mode based on improving students' participation and learning motivation has become the dominant mode[3].At present, the teaching effect of the initial online, get outstanding student's main body status, but for the students' cognitive regularity, learning motivation research is not thorough, for through the teaching design promote students participation practice effect is not outstanding, to study effect of evaluation method and result oriented utilization does not reach the designated position, this also is bound to become the future based on the focus of the digital teaching resources, teaching model reform and breakthrough.

\section{ACKNOWLEDGMENT}

This work is supported by Beijing Educational Informatization Project-research on the new teaching mode based on digital educational resources.

\section{REFERENCES}

[1] Education Informatization 2.0 Action Plan. No.6 [2018], http://www.moe.gov.cn/srcsite/A16/s3342/201804/ t20180425_334188.html

[2] Xu Zhaoming. Discussion on the construction of digital teaching resource sharing Platform [J].China's Modern Educational Equipment, 2009 (13): 24-26.

[3] Tan Yingsi. Review of research status of mixed teaching at home and abroad [J].Chinese Journal of Multimedia and Network Teaching, 2019 (8) : 4243. 